\title{
The role of motivation in the formation of professional competence in foreign students in the pre-university period
}

\section{Papel que juega la motivación en el desarrollo de la competencia profesional en los estudiantes extranjeros en la etapa de educación preuniversitaria}

\author{
Kositsyna Evgeniya \\ Peoples' Friendship University of Russia (RUDN University), Moscow, Russian \\ Federation \\ ORCID ID: https://orcid.org/0000-0001-5117-8835 \\ Anastasia Lakhaeva \\ Peoples' Friendship University of Russia (RUDN University), Moscow, Russian \\ Federation \\ ORCID ID: https://orcid.org/0000-0002-7248-242X \\ Kotov Lev \\ Sechenov First Moscow State Medical University (Sechenov University), Russian \\ Federation \\ ORCID ID: https://orcid.org/0000-0003-4931-4820
}

Received 10-10-20 Revised 11-12-20 Accepted 01-13-21 On line 01-14-21

*Correspondence

Email: olfiss@ @ist.ru
Cite as:

Evgeniya, K., Lakhaeva, A., \& Lev, K. (2021). The role of motivation in the formation of professional competence in foreign students in the pre-university period. Propósitos $y$ Representaciones, 9 (SPE1), e867. Doi: http://dx.doi.org/10.20511/pyr2021.v9nSPE1.867 


\section{Summary}

The article analyzes the role of motivation in the professional development of a person. The article proves that the formation of professional competence should begin in the period of training foreign students. The author studies the concept of professional competence and its components. The article explains the role and significance of motivational processes in the formation of professional competence. The key role in the formation of professional competence in the conditions of preparatory departments is played by Russian as a foreign language. Russian as a foreign language becomes a motivational regulator of educational activity. Knowledge of the Russian language helps a foreign student to consider educational goals as personally significant.

Keywords: motivation, professional competence, foreign students.

\section{Resumen}

En el artículo se analiza el papel que juega la motivación en el desarrollo profesional de la personalidad. Está comprobado que el desarrollo de la competencia profesional debe empezar en la etapa de formación preuniversitaria de los estudiantes extranjeros. Se valora el concepto de competencia profesional y sus componentes. Se fundamenta la función y la importancia de los procesos motivacionales en el desarrollo de la competencia profesional. El idioma ruso como lengua extranjera juega un papel clave en el desarrollo de la competencia profesional bajo las condiciones de las facultades preparatorias. El idioma ruso como lengua extranjera se está convirtiendo en un regulador motivador de las actividades de aprendizaje. El conocimiento del idioma ruso conduce a la aceptación de las tareas educativas como significativas para la persona.

Palabras clave: motivación, competencia profesional, extranjeros.

\section{Introduction}

Motivation to obtain professional competence is the basis for training foreign students in the pre-university period. Foreign students coming to Russia face the need to learn Russian as a foreign language. It is the Russian language in the pre-university period that becomes the basis for the formation of professional competence.

However, the study of motivation has not been given due attention for quite a long period of time. As a rule, motivation was confined to the inducement to do tasks in accordance with the curriculum. Methodologists described and analyzed cases of positive or negative motivation. As for the idea of developing teaching methods and techniques, it was mostly about turning an educational process into an entertainment.

The new time has set new tasks for psychologists and professors of Russian as a foreign language, related to the studies concerning the influence of motivation on the formation of professional competence.

The relevance of the study is as follows:

1) methodologists are to choose the optimal methodological techniques that meet the needs of students (social status and need for learning Russian as a foreign language);

2) at the stage of pre-university training, the task is to maintain the internal motives of the individual associated with learning Russian as a foreign language in order to form professional competence;

3) mastering the culture of learning in a foreign language provides enhanced motivation to obtain professional competence;

4) motivation to obtain professional competence contributes to the socio-cultural development of the individual. 


\section{Discussion.}

\section{The concept of "professional competence" and its components}

Competence-based vocational training is a response of Russian education system to the changed social and economic life conditions. The competence-based approach is actively developed in the context of the Bologna process on the basis of the provisions from the "Strategy for the Modernization of the Content of Comprehensive Education" (2001) and "The Concept of Modernization of Russian Education System for the period up to 2010".

According to I.A. Zimnyaya (2003), there are three stages in the formation of the competence approach:

- the first stage (1960-1970). The stage is characterized with the formation of scientific apparatus of the competence approach and the introduction of such concepts as "competence" and "communicative competence" (Hymes);

- the second stage (1970-1990). The stage is related to the name of John Raven and his social competence theory. A distinctive feature of this period is extended frontiers of understanding the competence approach. Competence begins to be defined as a phenomenon consisting of multiple components which are relatively independent from each other and relate partly to the subjective sphere, and partly to the emotional one (Khutorsky, 2004). At this stage the educational goal is to obtain competence as the final result of training. Competence begins to be considered as personality traits;

- the third stage (from 1991 to date). This stage is characterized by the idea that scientific knowledge is the cognitive basis of competence. For instance, A. Andreev believes that "the main goal of the competence-based approach is to strengthen the practical orientation of education, going beyond the limitations of the "knowledge-abilities-skills (KAS)" educational space". According to the scholar, the imbalance between education and life can be rectified with the shift of the ultimate educational goal from knowledge to integral activity-practical skills, i.e. competence. This general line of reasoning is usually supported with social-economic argumentation, for example, with the fact that nowadays professions are turning into sort of shortterm competence packages, and the ability to perform certain functions is in more demand that knowledge itself (Andreev 2005, p.3).

Competence-based approach in higher education is manifested in integrative processes that reflect the general trends of vocational training of students.

One should understand that the communicative approach is not limited to practice-oriented vocational training. Formed professional competencies help preparatory department students in further vocational training and self-training. The system-forming categories in competence-based professional training are "competence" and "competency". However, there is no common understanding of their definitions in the Russian psychological and pedagogical literature. A.I. Surygin believes that the concepts of "competence" and "competency" are semantically close, "not to mention identical" to such concepts as the content of education and education itself (Surygin 2000, p.98). However, most researchers believe that the existence of both two terms is legitimate.

According to "Soviet Encyclopedic Dictionary", competence is "knowledge and experience in a particular field" (Soviet Encyclopedic Dictionary 1981, p. 621), which corresponds to the cognitive approach based on the idea of knowledge as a value-significant and meaning-forming component. For example, according to "Strategy for the Modernization of the Content of Comprehensive Education" along with cognitive and functional-technological components competency includes motivational, ethic, social and behavioral elements, as well as the results of education (knowledge and skills), value orientation system, habits, etc. V.A. Bolotov and V.V. Serikov consider competency "a complex synthesis of cognitive, subject-practical and personal experience" (Bolotov \& Serikov 2003, p. 12).

According to V.I. Baidenko, competence is: "1. The ability to do something well, effectively in a 
wide format of contexts with a high-degree self-regulation, self-reflection, self-esteem, fast and flexible adaptive response to the dynamics of circumstances and environment. 2. Compliance with qualification characteristics with regard to the demands of local and regional (federal) needs (requests) of the labor market. 3. The ability to perform specific types of activities and jobs depending on the task set, problem situations, etc." (Baidenko 2004, p. 11). Competences are succinctly embedded in the framework of the educational process. They can be acquired as a result of training and assessment, which is aimed to confirm trainees' mastery. E.F. Zeer and E. Symanyuk believe that professional activities are provided by the integrity and generality of actions, knowledge, and skills. The structure of competences is multi-dimensional. In addition to procedural (activity) knowledge, skills and abilities, the structure of competences includes motivation, emotions, and will. Competences are integrated into the actions, methods and techniques of problem solving learned by a person. They are organized into a single language system to model academic and professional profiles of higher education (Zeer \& Symanyuk, 2004).

In accordance with this interpretation of competence, competency is considered as the result of developed professionally significant competences. E.F. Zeer defines competence "as a set of knowledge in action" (Zeer 2005, p. 26-27).

I.A. Zimnyaya highlights the components of competence, such as: "a) readiness to demonstrate the quality in the activity or behavior; b) knowledge of means, techniques, programs to perform actions, solve social and professional tasks, implement the rules and codes which constitute the content of competence; c) experience in implementing expertise, i.e. skills; d) value-meaning relation to the content of competence and its personal importance; d) regulation of emotion and will as the ability to exercise and control manifestations of competence according to situations of social and professional interaction" (Zimnyaya 2003, p. 34-35). However, competency is not confined to a set of competences. Competency is defined by knowledge, experience, and skills. The competence of a professionally successful person determines the ability to mobilize them.

\section{The importance of motivation in the formation of professional competence}

First and foremost, the role of motivation in the formation of professional competence should be considered along with definitions of "motive", "need", and "motivation". Russian scholars consider motivation as "a set of internal and external driving forces that encourage a person to perform activity and give this activity a focus on achieving specific goals" (Volodina 2008, p. 100). Psychologists have found that needs induce actions. The behavioral manifestation of need is an impulse. Thus, an impulse is a manifestation of need, whereas need is a motive for action.

Psychological studies consider motives as criteria for "distinguishing specific types of activity such as educational activity, labor activity, etc. ... With its linkage to need, the motive has the function of inducing a person to act." Motives differ according to their criteria: "significance for the life and development of an individual; social activity, a source of motivation to solve a specific task; attitude to realizing; the place in the hierarchical structure of the need and motivation sphere" (Udaltsova 1998, p.72). The professional competence of foreign students is closely related to the study of the Russian language. E.A. Maslyko identifies motivational factors in the methodology of teaching a foreign language, i.e. "the factors of educational motivation, factors of cognitive motivation and factors of professional motivation. All these groups seem to overlap in the personal factor which ultimately forms motivation as a psychological reality" (Maslyko 1989, p. 28). Motivation is based on cognitive, educational, personal and professional motives.

\section{Foreign-language educational environment as a source of motivation for the formation of professional competence}

Speaking about the readiness of specialists to be involved in professional activities, it is necessary to take into account their ability to react to the conditions of an ever-changing environment. The determinants of professional competence are professional skills, defined as "the ability to independently apply professional knowledge, formed in the process of learning, in practice with a certain quality and for a certain time, within changing conditions" (Kozlachkov 
1987, p. 9). The quality of professional activity is influenced by objective and subjective factors that have a certain impact on the educational process.

Training foreign students at preparatory departments is a challenge that requires methodologists' special attention.

Consider the main methodological principles of teaching Russian as a foreign language:

1) focus on communication;

2) differential selection of the material;

3) functional-situational approach;

4) communicative sufficiency (Shatilov 1972).

When starting their study, foreign students get immersed in a foreign-language environment. It is the foreign-language educational environment that becomes a source of knowledge replenishment due to the foreign-language information that Russian as a foreign language gives access to. Here the key role is played by contextual motivation associated with the condition of educational activity. A specially organized educational environment allows foreign students to acquire necessary knowledge, skills and abilities.

The educational environment was studied by S.V. Tarasov \& A.E. Maron (2010), V.A. Jasvin (2001) and other researchers. V.A. Yasvin (2001) defines the educational environment as a system that creates conditions for the development of students' personality.

The learning environment can have both positive and negative impact on personal development. Russian psychologists G.A. Kovalev, Yu.G. Abramov (1996) \& S.L. Rubinstein (1969) consider the educational environment as a set of educational techniques, educational work and educational process. Russian psychologists have proved that a specially organized environment will not suffice the development of a professional's personality. Certain qualities of the subject of the educational process become professionally significant in learning process. In the process of learning, there is a process of "forming higher forms of professional consciousness that allow an individual to change the structure and content of their professional activity and thereby realizing their own development rather than to realize the world of professional activity and transform it in accordance with the tasks emerging" (Nechaev 2005, p.34). Professionalization is based on different qualities of students. The existing traditional models are based on a combination of didactic and psychophysiological approaches. From the point of language training, one may distinguish conscious-practical, intensive and communicative trainings.

To form professional competencies it is necessary to create or maintain the educational environment.

Productive creative activity of an individual in the educational process is related to their cognitive motivation.

Educational motivation is linked to motivating preparatory department students to learn Russian as a foreign language. If we talk about foreign students' educational motivation, it is advisable to distinguish internal motivation associated with internal incentives, and external motivation, related to what is happening in the class. The culture of the country, its way of life and foreigners' desire to get integrated into it contribute to the formation of educational motivation. The instrumental function is related to the listener's confidence that the Russian language is a means to achieve life goals. The Russian language is an important component of vocational training in Russian universities. T.N. Astafurova supposes that "introduction of cognitive, sociopsychological and cultural categories in scientific apparatus allows us to consider... language acquisition... as the acquisition of communicative competence, which is one 
of the central concepts of communicative-functional linguistics, which emerged on the border of linguistics and methods of teaching foreign language, and nowadays is moving toward the convergence of linguistic theories with the practice of a person's verbal behavior" (Astafurova 1966, p.54). Communicative competence is related to the ability to communicate in foreign language in oral and written forms, as well as expertise in the culture of the country of the language learned. Professional competence consists of teaching, educating and developing competences.

Professional and communicative competence is determined by the degree of proficiency in Russian as a foreign language, the level of listening and speech skills, etc. Thus, preparatory department students in the course of training master their foreign-language pronunciation, learn how to correctly make sentences, perceive oral and written speech in everyday communication and professional sphere.

The motivational and stimulating aspect is related to the formation of students' attitude to the use of knowledge, skills and abilities in a communicative act.

The formation is achieved through the use of educational situations in a natural speech. The educational process should be based on the use of age and individual characteristics, use of texts, available for assimilation, as well as communicative and stimulating settings related to the performance of speech tasks.

The principle of a differentiated approach to teaching foreign languages was considered by many Russian researchers (I.L. Bim (1985), I.A. Zimnyaya (1980), R.P. Milrud (1996), A.A. Mirolyubov (1986), E.I. Passov (1991), etc.). The classical traditional teaching scheme is focused on memorizing the material. Professional competence, however, requires creative thinking. Even ordinary speech intentions cannot be standardized. At the preparatory departments, the Russian language as a foreign language is acquired by students as a subject, on which their educational activity is focused.

\section{Conclusiones}

The key objective of the system of pre-university training is to form a competent person, psychologically prepared for further professional development. The study shows that the main purpose of training at preparatory departments is to form professional competence.

Nowadays there are some contradictions between the knowledge and skills formed in foreign students in the pre-university period, and the professional competences, necessary for successful education in the chosen specialty. The formation of foreign students' motivation to obtain professional competence is particularly relevant for several reasons. First, professional competence allows foreign students to solve educational tasks. Second, the success of further educational activities is related to the extent to which professional-subject foreign-language speech and situational determinants of professional activity are integrated into the personality structure.

\section{References}

Abulhanova-Slavskaya, K.A. (1960) Personal psychology and activities. Moscow, Russia, 335

Andreev, A.L. (2005) Competence-based educational paradigm: experience of philosophical and methodological analysis. Pedagogika. No 4, 19-27

Astafurova, T.N. (1966) Pragmatics of business communication. Science Journal of Volgograd State University. No 1, 145-175

Baydenko, V.I. (2004) Competence in professional education (comprehending competence-based approach). Higher education in Russia. No 11, 3-14

Bim, I.L. (1985) Approach to exercises from the point of hierarchy of objectives and goal. Foreign languages at school. No 5, 36-37

Bolotov, V.A. \& Serikov, V.V. (2003) Competence approach model: from idea to curriculum. Pedagogika. No 10, 8-14

Khutorsky, A.V. (2004) Workshop on didactics and modern teaching techniques. Saint Petersburg, Russia, 541 
Kovalev, G.A. \& Abramova, Yu.G. (1996) Spatial factor at school: alternatives and prospects // To teachers about childhood ecology. Moscow, Russia, 256

Kozlachkov, V.I. (1987) Didactic conditions for the skill formation in the process of practical training. Abstract from PhD thesis. Moscow, Russia, 17

Kuchma, T.V. (1991) Speaking training at non-linguistic universities based on the use of motives for professional communication. PhD thesis. Moscow, Russia, 227

Larionova, O.G. (2007) Integration of person-focused and competence-based approaches in contextual education (based on Mathematics teachers' training material). Abstract from $\mathrm{PhD}$ thesis. Moscow, Russia, 54

Maslyko, E.A. (1989) Motivational factors in the organization and methodology of teaching foreign languages. Motivational aspects of vocation-oriented teaching foreign languages. Collection of academic papers. Perm, Moscow, Russia, 1989, 221

Milrud, R.P. (1996) Modern methodological standard of teaching foreign languages at school. Foreign languages at school. No 1, 5-19

Mirolyubov, A.A. (1986) Teaching foreign languages in the context of school reform. Foreign languages at school. No 2, 4-11

Nechaev, N.N. (2005) Professionalism as the basis of professional mobility. Moscow, Russia, 92

Passov, E.I. (1991) Communicative approach to teaching foreign-language speaking. Moscow, Russia, 190

Rubinstein, S.L. (1969) Human and the world. Methodological and theoretical problems in psychology. Moscow, 1991, 374

Shatilov, S.F. (1977) The main issues of methodology of teaching grammar at secondary school. Leningrad (Saint Petersburg), 1977, 285

Soviet encyclopedic dictionary (1981) Moscow, Russia, 1981, 1599

State educational standards in the comprehensive education system (2002). Theory and practice. Eds.: Lednev, V.S. \& Nikandrov N.D. \& Ryzhakov M.V. Moscow, Russia, 63

Surygin, A.I. (2000) The theoretical basis of teaching students in foreign languages. Saint Petersburg, Russia, 230

Tarasov S.V. \& Maron A.E. (2010) Innovational development of education system, based on methodology of environmental approach. Man and Education. No 3 (24), 14-18

Udaltsova, M.V. (1998) Sociology of management. Moscow, Russia, 684

Volodina, E.V. (2008) Formation of vocation-focused foreign-language communicative competence in the future vocational training teachers. PhD thesis. Moscow, 159

Yasvin, V.A. (2001) Educational environment: from modelling to design. Moscow, Russia, 356 Zeer, E. F. \& Symanyuk, E. (2004) Modernization of professional education: competencebased approach. The Education and Science Journal. Ural News. No 3, 42-53

Zimnyaya, I.A. (1980) Psychological and pedagogical problems of interaction between a teacher and students. Moscow, Russia, 180

Zimnyaya, I.A. (2003) Key competences: a new paradigm of the education results. Higher education today. No 5, 34-42

*The publication has been with the support of the "RUDN University Program 5-100". 